\title{
Assessment of the antibacterial effect of Khaya senegalensis on some Gram-negative bacteria
}

\author{
Victorien Dougnon ${ }^{1 *} \mathbb{0}$, Edna Hounsa ${ }^{1}$, Hornel Koudokpon ${ }^{1}$, Eric Agbodjento ${ }^{1}$, Anny Afaton ${ }^{1}$, Kevin Sintondji ${ }^{1}$, \\ Jean Robert Klotoe', Julien Segbo ${ }^{1}$ and Lamine Baba-Moussa²
}

\begin{abstract}
Background: The matter of antimicrobial resistance evokes the urgency to explore alternatives to the antibiotics traditionally used for microbial infections. This study aimed to elucidate the mechanism of action of the antibacterial effect of Khaya senegalensis liable for bacterial strains responsible for diarrheal infections.

Results: The data collected indicate that the bacterial strains tested (Salmonella Typhimurium ATCC 14028, Escherichia coli ATCC 25922, Shigella spp. and Salmonella spp.) were sensitive to the extracts of Khaya senegalensis (Desr.) A.Juss. (aqueous and hydro-ethanol) to varying degrees. The hydro-ethanolic extract was active on all strains with a MIC of $25 \mathrm{mg} / \mathrm{mL}$ coupled with a bactericidal effect. The aqueous extract was only active on the Salmonella spp. strain. Membrane permeability test data show that Khaya senegalensis extracts affect the bacterial strains tested by attacking the stability of their outer membrane. This potential indicated by the high percentage of membrane destabilization of the bacteria is significantly $(p<0.05)$ better than that of cefixime used as a reference.

Conclusion: This study revealed that Khaya senegalensis destroys Gram-bacteria by attacking the stability of their cytoplasmic membrane. These data provide for the first time the mode of action of Khaya senegalensis extracts concerning their antibacterial activity.
\end{abstract}

Keywords: Khaya senegalensis, Mode of action, Antibacterial activity, Gram-negative Bacteria

\section{Background}

Infectious diseases constitute a serious public ill health thanks to their frequency and gravity especially in developing countries (Bourgeois et al. 2016). Among these diseases, diarrheal diseases are the foremost fatal, especially in children from West Africa. In fact, these diarrheal diseases are liable for 1.8 million deaths annually worldwide where $90 \%$ are children under the age of five living in developing countries (Bryce et al. 2005). Diarrheal diseases represent the third reason of death from infectious

\footnotetext{
*Correspondence: victorien.dougnon@gmail.com

${ }^{1}$ Research Unit in Applied Microbiology and Pharmacology of Natural Substances, Research Laboratory in Applied Biology, Polytechnic School of Abomey-Calavi, University of Abomey-Calavi, Abomey-Calavi, Benin Full list of author information is available at the end of the article
}

diseases of all ages and the 5th cause of premature death worldwide (WHO 2014). According to WHO, in Benin, diarrheal diseases are one of the main causes of morbidity. Indeed, they have a direct impact on the costs associated with health care, including several factors such as consultation, medication and in some cases, hospitalization, which represents a burden on household spending (WSP-ESI-Benin 2012). The pathogens of diarrheal diseases are mainly bacteria (Djague et al. 2020).

Medical therapy is based on the use of conventional antibiotics and antidiarrheal drugs. The use of antimicrobials should not be done routinely. In fact, a clinical distinction is made between diarrheal episodes caused by enterotoxigenic $E$. coli and those caused by rotavirus or Cryptosporidium against which antimicrobial drugs 
are ineffective (WHO 2005). Moreover, this use of antimicrobials sometimes presents undesirable effects and favors the development of resistant bacteria. Nowadays, antimicrobial resistance constitutes a real public health problem for the effective management of infectious diseases (Nahrgang et al. 2018). The most of the bacteria responsible for diarrheal episodes develop resistance to the antibiotics used in modern therapy (Ahmed et al. 2000; Qu et al. 2016). In addition, the anti-diarrheal drugs used until now are often ineffective and do not succeed in preventing dehydration and improving nutritional status, which should be the main objectives of treatment (WHO 2005). Concerning drug treatments that have shown some effectiveness, namely the use of oral rehydration solutions (ORS) to reduce fluid and electrolyte losses in diarrheic patients, it should be noted that in rural and semi-urban areas, the lack of knowledge of patients regarding their application limits their use (WHO 2005). In addition, the lack of qualified health personnel in most rural African communities and the high cost of therapies in case of severity do not contribute to a better management of diarrheal disease (WHO 2005). In the search for alternative solutions, World Health Organization (WHO) had initiated a diarrheal disease control program based on traditional medicine practices and prevention approaches (WHO 2011). This approach is even more justified given that about $80 \%$ of the population of developing countries like Benin continue to use traditional medicine based on the use of medicinal plants for their primary health needs (WHO 2002).

Khaya senegalensis (Desr.) A.Juss. (K. senegalensis) is a medicinal plant from the Beninese flora widely used in traditional African medicine (Akoègninou et al. 2006). In West Africa it is a plant that benefits from a multiple use value mainly used for bacterial infections (Issa et al. 2018). In southern Benin, the practitioners of traditional medicine used $K$. senegalensis for the treatment of bacterial infections, particularly diarrheal infectious (Akoègninou et al. 2006). Literature data confirmed the antibacterial potential of the stem bark of the $K$. senegalensis on bacterial strains such as Salmonella Typhi, Salmonella Paratyphi and Salmonella Typhimurium (Abdallah et al. 2016; Katawa et al. 2018; Koudoro Yaya et al. 2018; Ugoh et al. 2014). These data suggest the antibacterial potential of the plant and justify its use in traditional medicine in the treatment of bacterial infections. However, despite the plurality of data available on the biological activities of this plant, particularly on its antimicrobial properties, it is clear that no study has so far explored the mechanism of action of its antibacterial activity. This study aimed to elucidate the mode of action of the antibacterial effect of aqueous and hydro-ethanolic extracts of $K$. senegalensis on Gram-negative bacteria involved in diarrheal infections.

\section{Methods \\ Plant material}

The plant material used in this study consists of fresh stem bark of Khaya senegalensis (Desr.) A.Juss. These samples were collected in Abomey-Calavi in July 2020 and certified at the National Herbarium of Benin at the University of Abomey Calavi under the identification number YH435/HNB.

\section{Biological material}

The strains of Gram-negative bacteria involved in the occurrence of diarrheal infections, obtained from the Research Unit in Applied Microbiology and Pharmacology of natural substances, University of Abomey-Calavi, Benin were the biological material used. The characteristics of these strains are summarized in Table 1.

\section{Study methods Phytochemical screening of the plant}

This part of the study consisted of the qualitative identification of eleven major phytochemical classes in the powder of the stem bark of $K$. senegalensis according to the method described by Houghton and Raman (1998). These are tannins, gallic tannins, flavonoids, anthocyanins, leuco-anthocyanins, alkaloids, mucilages, reducing compounds, sterols, terpenes and saponosides.

\section{Preparation of plant extracts}

The bark of the plant stems collected, cleaned and dried at room temperature at the Research Unit of Applied Microbiology and Pharmacology of natural substances was ground to powder using the Retsch electric mill. Two types of extraction (aqueous and hydro-ethanolic) were obtained following the methodology used by Klotoé et al. (2020). Briefly, fifty (50) grams of powder were macerated in $500 \mathrm{ml}$ of distilled water for the aqueous extract and in $500 \mathrm{ml}$ of the mixture of water and ethanol at $50 \% \mathrm{v} / \mathrm{v}$ for the hydro-ethanolic extract. After $72 \mathrm{~h}$ of agitation at room temperature, the homogenate obtained was filtered three times on cotton wool and once on Wattman paper

Table 1 Bacterial species used for antibacterial tests

\begin{tabular}{ll}
\hline Bacterial species & Origin \\
\hline Salmonella Typhimurium ATCC 14,028 & Reference strain \\
Escherichia coli 25,922 & Reference strain \\
Shigella spp. & Clinical strain \\
Salmonella spp. & Clinical strain \\
\hline
\end{tabular}


$\mathrm{N}^{\circ}$ 1. Crude extract was obtained after evaporation at a temperature of $40^{\circ} \mathrm{C}$ in an oven (oven).

\section{Determination of bioactive molecules of the extracts}

\section{- Determination of total polyphenols}

The method of Singleton et al. (1999) using the commercial Folin Ciocalteu Reagent (FCR) was adopted. Briefly, $50 \mu \mathrm{L}$ of the extract was mixed with $250 \mu \mathrm{L}$ of the FCR (10 times diluted in distilled water) and $750 \mu \mathrm{L}$ of an aqueous solution of sodium carbonate $\mathrm{Na}_{2} \mathrm{CO}_{3}$ (7.5\%). After $8 \mathrm{~min}$ of incubation, $950 \mu \mathrm{L}$ of distilled water was added and mixed with the vortex and incubated for $2 \mathrm{~h}$. Optical densities (OD) were read at $760 \mathrm{~nm}$ using a CECIL CE 2041 spectrophotometer. The reading was made against a blank consisting of a mixture of $250 \mu \mathrm{L}$ of FCR, $750 \mu \mathrm{L}$ of $\mathrm{Na}_{2} \mathrm{CO}_{3}$ and $1 \mathrm{~mL}$ of distilled water. Samples were prepared in triplicates. Gallic acid $(0-200 \mu \mathrm{g} / \mathrm{mL})$ was used as standard reference. The total polyphenols content was determined as mg of gallic acid equivalent/g of extract (mg GAE/g) from the equation of the linear calibration curve $(y=0.0012 x-0.0388$ with $R^{2}=0.9988$ ).

\section{- Determination of total flavonoids}

Flavonoids contents were measured by the method using aluminium trichloride $\left(\mathrm{AlCl}_{3}\right)$ described by Zhishen et al. (1999) and used by Klotoé et al. (2020). $500 \mu \mathrm{L} \mu \mathrm{L}$ of $\mathrm{AlCl}_{3}(2 \%), 500 \mu \mathrm{L}$ of the extract and $3 \mathrm{~mL}$ of methanol were mixed thoroughly. The blank consists of $500 \mu \mathrm{L}$ of $\mathrm{AlCl}_{3}$ and $3.5 \mathrm{~mL}$ of methanol. Absorbance reading was done at the spectrophotometer at $415 \mathrm{~nm}$ after $10 \mathrm{~min}$ of incubation. Samples were prepared in triplicates. Rutin $(0-1 \mathrm{mg} / \mathrm{mL})$ was used as a reference standard. Total flavonoids content was determined as $\mathrm{mg}$ of rutin equivalent/g of extract $(\mathrm{mgRuE} / \mathrm{g})$ from the equation of the linear calibration curve $(y=44.135 x-0.1893$ with $R^{2}=0.9909$ ).

\section{In vitro Antibacterial activity of plant extracts}

Three steps were followed for performing this antibacterial test.

\section{- Preparation of extracts and sterility test}

$100 \mathrm{mg} / \mathrm{mL}$ of extract solution (aqueous and hydroethanolic) were prepared in distilled water. To verify the sterility of these prepared extract solutions an inoculation of aliquots of each solution was applied on Mueller Hinton medium according to the methodology described by Agbankpe et al. (2016).

\section{- Sensitivity test of bacterial strains to extracts}

A portion of pure 24-h colony from Mueller Hinton's medium from each strain was emulsified in $5 \mathrm{~mL}$ of physiological water to obtain a turbidity of 0.5 on the MAC Farland scale. Each inoculum was inoculated by swabbing onto plates containing Mueller Hinton agar (CA-SFM 2020). $50 \mu \mathrm{L}$ of each extract $(100 \mathrm{mg} / \mathrm{mL})$ was placed in the $6 \mathrm{~mm}$ diameter wells. A negative control was prepared with sterile distilled water. Standard antibiotic discs (Ciprofloxacin, Cefixime and Gentamicin) were used as positive controls. For an hour, the Petri dishes were pre-incubated at room temperature for the pre-diffusion of the substances and then incubated at $37^{\circ} \mathrm{C}$ in an oven for $18 \mathrm{~h}$. The test was repeated three times. The incubated plates were examined to measure the zones of inhibition. The standard used for reading the results of the antibiogram tests is presented in Table 2 (Tsirinirindravo and Andrianarisoa 2010; WHO 2002).

\section{- Determination of the Minimum Inhibitory Concen- tration (MIC) and Minimum Bactericidal Concen- tration (MBC) of active extracts}

This part of the study following the method applied by Lègba et al. (2018). It consisted of the 96-well plate method. $100 \mu \mathrm{L}$ of the initial extract solution at the concentration of $100 \mathrm{mg} / \mathrm{mL}$, were added to $100 \mu \mathrm{L}$ of Mueller-Hinton broth. A series of dilution from well to well was carried out and then $100 \mu \mathrm{L}$ of various bacterial suspensions were added. Positive $(100 \mu \mathrm{L}$ of $\mathrm{MH}$ broth added to $100 \mu \mathrm{L}$ of bacterial suspension) and negative controls $(100 \mu \mathrm{L}$ of $\mathrm{MH}$ broth added to $100 \mu \mathrm{L}$ of the extracts) were prepared. The microplates were incubated at $37^{\circ} \mathrm{C}$ for $24 \mathrm{~h}$. All the wells of the $\mathrm{MIC}$ at the higher concentrations were then inoculated on a Mueller Hinton agar then the Petri box were placed at $37{ }^{\circ} \mathrm{C}$ for $24 \mathrm{~h}$ for the determination of the MBC. The antibiotic power (AP) of each extract was then calculated with the formula MBC/MIC. The antibacterial effect or power is judged to be bactericidal

Table 2 Standard used for reading the results of antibiogram tests of plant extracts

\begin{tabular}{ll}
\hline Inhibitory diameter $(\boldsymbol{\Delta})$ & Germ sensibility \\
\hline$\Delta<7 \mathrm{~mm}$ & Resistant \\
$7 \mathrm{~mm} \leq \Delta<8 \mathrm{~mm}$ & Sensitive \\
$8 \mathrm{~mm} \leq \Delta<9 \mathrm{~mm}$ & Moderately sensitive \\
$\Delta \geq 9 \mathrm{~mm}$ & Very sensitive \\
\hline
\end{tabular}


or bacteriostatic based on the $\mathrm{AP}=\mathrm{MBC} / \mathrm{MIC}$. If $1 \leq \mathrm{AP} \leq 2$, the effect is bactericidal and if $4 \leq \mathrm{AP} \geq 16$, the effect is bacteriostatic.

\section{Permeability test outer membrane of Gram-negative bacteria} This test is based on the evaluation of the destabilizing power of the membrane of bacteria by plant extracts. It was determined according to the method employed by Djague et al. (2020). In a 96-well microplate, the MIC and $2 \mathrm{MIC}$ of the extract in triplicate were prepared by serial dilution. $100 \mu \mathrm{L}$ of the suspension of the tested bacteria $\left(1.5 \times 10^{6} \mathrm{CFU} / \mathrm{mL}\right)$ was added to all wells and the plate was incubated at $37^{\circ} \mathrm{C}$ for $24 \mathrm{~h}$. Cefixime was used as a positive control. Muller Hinton broth and bacterial suspension served as negative control. The optical densities were read at $405 \mathrm{~nm}$. The percentage of destabilization was calculated using the formula below:

$$
\% D=\left(A_{\mathrm{o}}-A_{\mathrm{s}}\right) / A_{\mathrm{o}} \times 100
$$

$\% D$ : Percentage of destabilization; $A_{\mathrm{o}}$ : Absorbance of the negative control; $A_{\mathrm{s}}$ : Absorbance of test samples.

\section{Data analysis}

The in vitro antibacterial test was repeated three times and the results were analyzed using Graph Pad 7 software. The quantitative variables were then presented as mean \pm standard deviation. ANOVA analysis of variance was used to compare the percentage of bacterial membrane destabilization between samples. The Student's $t$-test was used to analyze the quantitative composition in total polyphenols and flavonoids of the extracts. The significance level was set at $5 \%$.

\section{Results}

\section{Phytochemical composition}

Data collected for the phytochemical screening revealed the presence of tannins, flavonoids, leuco-anthocyanins, alkaloid, mucilage, reducing compounds and saponosides in the powder of stem bark of $K$. senegalensis.

Determination of total polyphenols and flavonoids content The extracts present interesting content of polyphenols and flavonoids. Hydro-ethanolic extract exhibited significantly $(p<0.05)$ higher total polyphenol and flavonoid content compared to aqueous extract (Table 3 ).

\section{Sensitivity test}

Aqueous and Hydro-ethanolic extracts of $K$. senegalensis were tested against E. coli ATCC 25922, Salmonella Typhimirium ATCC 14028, Shigella spp. and Salmonella spp. Results of antibiogram showed variable sensitivity depending on the type of extract. Indeed, on all bacterial strains tested, $K$. senegalensis aqueous extract was active
Table 3 Total polyphenols and flavonoids of extracts of Khaya senegalensis

\begin{tabular}{lcc}
\hline Extracts & $\begin{array}{l}\text { Total polyphenols } \mathbf{( m g} \\
\text { GAE/g) }\end{array}$ & $\begin{array}{l}\text { Total } \\
\text { flavonoids } \\
\text { (mgRuE/g) }\end{array}$ \\
\hline Aqueous & $32.37 \pm 3.30$ & $12.46 \pm 0.44$ \\
Hydro-ethanolic & $116.30^{*} \pm 0.46$ & $51.1^{*} \pm 6.74$ \\
\hline
\end{tabular}

Legend: *Significant difference between the extracts

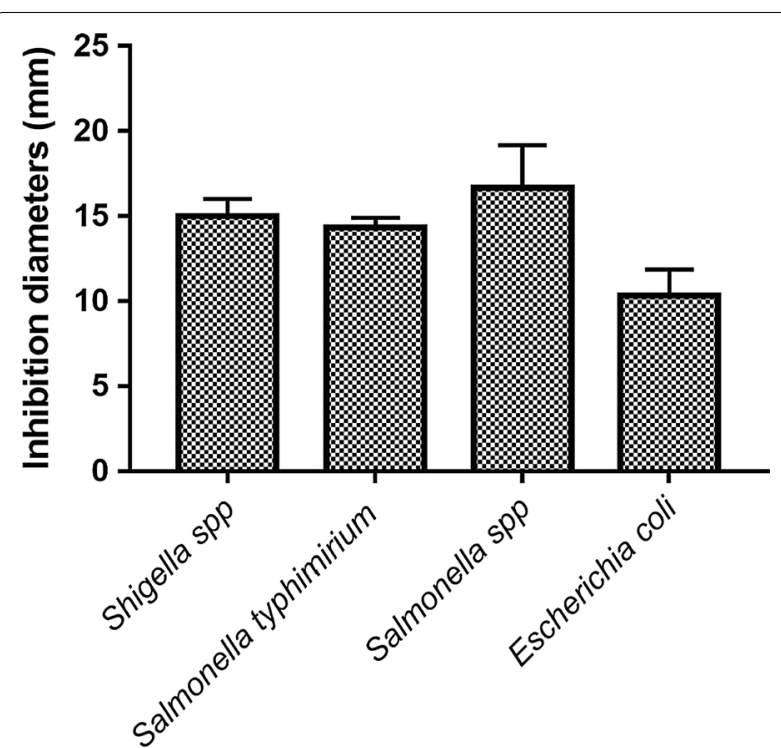

Fig. 1 Diameter of inhibition of the hydro-ethanolic extract of khaya senegalensis on the bacterial strains

only on Salmonella spp. with an inhibition diameter of $14 \pm 1 \mathrm{~mm}$. The hydro-ethanolic extract was active on all strains tested with variable activity (Fig. 1). The best antibacterial activity for this hydro-ethanolic extract was obtained on Salmonella spp. $(17 \pm 2.51 \mathrm{~mm}$ as inhibition diameter).

\section{MIC, MBC and AP of the extracts studied on the tested strains}

The collected data related to MIC, MBC and AP are presented in Table 4. Analysis of these data indicates that the MIC was $25 \mathrm{mg} / \mathrm{ml}$ for all strains sensitive to both hydroethanolic and aqueous extracts. The same observation is made for the MBC. These observations were used to determine the antibiotic power of these active extracts $(\mathrm{AP}=1)$.

\section{Effects of extracts on outer membrane permeability of bacterial strains}

Figure 2 presents the results of the permeability test of the outer membrane of bacteria strains. The analysis of 
Table 4 Minimum inhibitory concentration, minimum bactericidal concentration and the antibiotic potency of the plant extracts

\begin{tabular}{|c|c|c|c|c|c|}
\hline \multirow[t]{2}{*}{ Extracts } & \multirow[t]{2}{*}{ Parameters } & \multicolumn{4}{|l|}{ Bacterial strains } \\
\hline & & $\begin{array}{l}\text { Salmonella Typhimurium } \\
\text { ATCC } 14,028\end{array}$ & $\begin{array}{l}\text { Escherichia coli ATCC } \\
25,922\end{array}$ & Shigella spp. & $\begin{array}{l}\text { Salmonella } \\
\text { spp. }\end{array}$ \\
\hline \multirow[t]{3}{*}{ Aqueous extract } & $\mathrm{CMI}(\mathrm{mg} / \mathrm{mL})$ & - & - & - & 25 \\
\hline & $\mathrm{CMB}(\mathrm{mg} / \mathrm{mL})$ & - & - & - & 25 \\
\hline & $\mathrm{AP}$ & - & - & - & 1 \\
\hline \multirow[t]{3}{*}{ Hydro ethanolic extract } & $\mathrm{CMI}(\mathrm{mg} / \mathrm{mL})$ & 25 & 25 & 25 & 25 \\
\hline & $\mathrm{CMB}(\mathrm{mg} / \mathrm{mL})$ & 25 & 25 & 25 & 25 \\
\hline & AP & 1 & 1 & 1 & 1 \\
\hline
\end{tabular}

$A P$ antibiotic potency, $M I C$ minimum inhibitory concentration, $M B C$ minimum bactericidal concentration

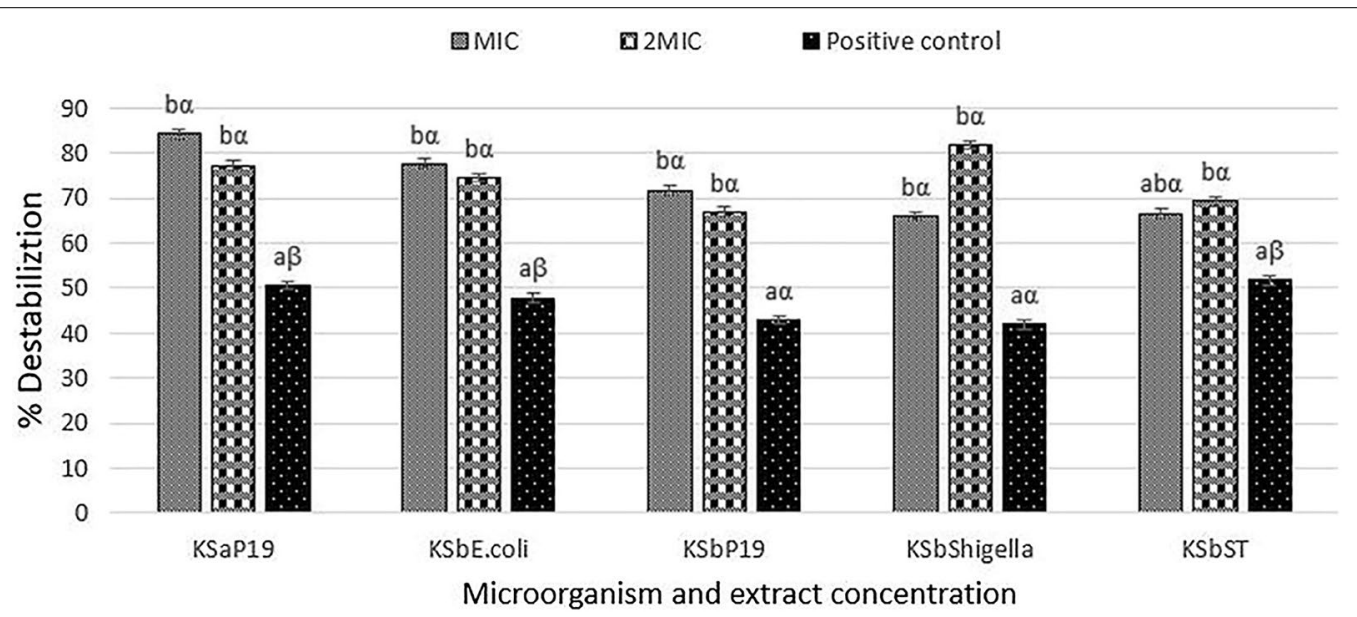

Fig. 2 Effect of destabilization of outer membranes of various bacteria by Khaya senegalensis. Legend: For same microorganism, bars carrying same letter $(a, b)$ are not significantly different while for same concentration, bars carrying the same Greek alphabet $(a, \beta)$ are not significantly different $(p>0.05)$, Waller Duncan. KSa: Aqueous extract; KSb: hydro-ethanolic extract

the data shows that the extracts studied complexed more divalent ions (increase of the destabilization percentage) than the positive control (Cefixime) at the concentrations tested (MIC and 2 MIC). However, no significant difference is to be reported between the effect obtained (percentage of destabilization) for MIC and 2 MIC $(p>0.05)$. The same trend is obtained regardless of the microorganism.

\section{Discussion}

This study aimed at providing scientific data on the mechanism of action of the antibacterial effect of $K$. senegalensis extracts. Data from the qualitative screening of K. senegalensis stem bark powder indicate the presence of tannins, flavonoids, leuco-anthocyanins, alkaloid, mucilage, reducing compounds and saponosides. In addition the extracts studied showed richness in total polyphenols and flavonoids. Similar observations were reported by Ugoh et al. (2014) in a study conducted in Nigeria. These observations are in agreement with the richness in polyphenolic compounds of plants of the same botanical family (Meliaceae) as K. senegalensis (John et al. 2014; Olatunji et al. 2021; Saleem et al. 2018). These data translating a richness in bioactive molecules of $K$. senegalensis could justified the use of the plant in the traditional treatment of diseases in several African pharmacopoeias (Abdel-Wareth et al. 2014). Furthermore, the difference observed between the polyphenolic compound content of the two extracts studied could be explained by the influence of the extraction solvent. Indeed, it is documented in the scientific literature that the extraction solvents have an influence on the quantity of bioactive molecules concentrated in the plant extracts (Babbar et al. 2014; Dirar et al. 2019; Do et al. 2014). In this study, the hydroethanol extract showed the best content of total polyphenols and flavonoids. This reflects that the mixed solvent (water-ethanol) concentrated more bioactive molecules than water. These data corroborate those reported by several authors who underlined the strong capacity of mixed solvents in the extraction of total polyphenols and 
flavonoids (Bourgou et al. 2016; Do et al. 2014; Mohammedi and Atik 2011; Venkatesan et al. 2019; Vieito et al. 2018). Trabelsi et al. (2012) justify this extraction capacity of mixed solvents by the increased solubility of bioactive compounds in this type of solvent.

Data obtained from the in vitro antibacterial test indicate that $K$. senegalensis bark is endowed with antibacterial properties on the strains involved in the diarrheal infections tested in this study. From the two extracts tested, the hydro-ethanolic extract was active on all bacterial strains with a Minimum Inhibitory Concentration (MIC) of $25 \mathrm{mg} / \mathrm{mL}$ coupled with a bactericidal effect. This antibacterial potential of the $K$. senegalensis could be justify by the existence of bioactive compounds such as flavonoids, tannins, alkaloids identified in the stem bark of $K$. senegalensis. Indeed, these bioactive molecules are known for their antimicrobial power referring to several reports in the literature (Djague et al. 2020; Kabir et al. 2015; Scalbert 1991). Specifically, some data in the literature attribute the antimicrobial activity of medicinal plants mainly to their polyphenolic compounds (Ghimire et al. 2017; Miklasińska-Majdanik et al. 2018). Indeed, these secondary metabolites are known to be responsible for a variety of biological activities of medicinal plants. Among them, flavonoids are one of the most studied polyphenolic compounds for their antibacterial properties (Cushnie and Lamb 2005; Farhadi et al. 2019). Similarly, tannins are a group of polyphenolic compounds that are very active in antimicrobial activities (Maisetta et al. 2019). Other data in the literature report the antimicrobial potential of alkaloids (Cushnie et al. 2014; Othman et al. 2019). These data justify the correlation, reported by several authors, between the antibacterial activity of K. senegalensis and these bioactive compounds (Abdallah et al. 2016; Kubmarawa et al. 2009; Ugoh et al. 2014). However, the difference of the antibacterial activity of the extracts observed in this study could be explained by the difference of their polyphenolic compounds content. Indeed, the hydro-ethanolic extract (the most active on the inhibition of the studied bacterial strains) is richer in polyphenolic compounds than the aqueous extract. These data show that the intensity of the biological activity of medicinal plant extracts is proportional to their content of bioactive compounds (Wang et al. 2016).

However, the anti-salmonella power of $K$. senegalensis obtained in the present study is similar to that reported by Ugoh et al. (2014) on Salmonella enterica subsp. enterica serovar Typhi strain. On the other hand, the comparison of the data of the present study with those obtained by Abdallah et al. (2016) and Katawa et al. (2018) shows opposite results. Except for Salmonella spp., the aqueous extract was inactive on the other three tested strains $(E$. coli, Salmonella Typhymirium and Shigella spp.) while the study of Abdallah et al. (2016) inform, for the same type of extract (aqueous extract), an inhibition of $E$. coli, Salmonella spp. and Shigella spp. with an MIC varying between 12.5 and $25 \mathrm{mg} / \mathrm{mL}$. Katawa et al. (2018), on the other hand, showed contrary to our data that the hydro-ethanolic extract of de K. senegalensis was not active on Salmonella Typhimirium strain but active on other Salmonella strains (Salmonella Typhi, Salmonella enterica and Salmonella Paratyphi). This discrepancy in results observed could be attributed to the influence of environmental factors on the composition of secondary metabolites in medicinal plants (Borges et al. 2017; Liu et al. 2016).

Several models were used to study the mode of action of antibacterial agents in relation to different bacterial targets (Pinto et al. 2017). In this study the permeability test of the outer membrane of bacteria was adopted to evaluate the mode of action of aqueous and hydroethanolic extracts of the stem bark of $K$. senegalensis against Salmonella Typhimurium ATCC 14028, Escherichia coli ATCC 25922, Shigella spp. and Salmonella spp; four strains involved in diarrheal infections. The data obtained highlight a remarkable potential for destabilizing the membrane of the bacterial strains of the extracts tested with a better effect compared to Cefixime used as a reference. These observations reflect that the extracts have a more enhanced mode of action on the destabilization of the outer membrane of the bacterial strains tested than Cefixime. Similar results were reported by Djague et al. (2020) for different extracts of Garcinia kola and Alchornea cordifolia and Polymyxin B used as a reference in their study and which has the same mode of action as cefixime. Moreover, with regard to their phytochemical composition, the mode of action of the antibacterial activity of the extracts tested on strains responsible for diarrheal infections can be attributed to phenolic compounds (flavonoids, tannins etc.). Indeed, these phenolic compounds are able to destabilize the external membrane of bacteria by complexing the divalent cations that stabilize them (Frirdich and Whitfield 2005; Vaara 1992). This antibacterial action promotes the bursting of the cytoplasmic membrane and alterations in Ionic homeostasis between the intracellular and extracellular compartments of Gram-negative bacteria (Trombetta et al. 2005). Thus, the membrane antigens responsible for the virulence of bacteria will be affected. These observations explain the destabilizing effect of $K$. senegalensis extracts for the bacterial membrane of the strains tested.

This study allowed to elucidate for the first time the mode of action of the antibacterial effect of K. senegalensis regarding its antibacterial activity, compared to the scientific literature currently available on the antibacterial properties of this plant. Such data evoke prospects 
for precision-oriented research on the mechanism of action of antibacterial effects of medicinal plants. This would optimize the search for new bioactive molecules for the fight against antimicrobial resistance.

\section{Conclusion}

This study revealed a variation in the antibacterial activity of aqueous and hydro-ethanolic extracts of $K$. senegalensis on strains of Salmonella Typhimurium ATCC 14028, Escherichia coli ATCC 25922, Shigella spp. and Salmonella spp. involved in diarrheal infections. The hydro-ethanolic extract showed better activity compared to the aqueous extract. These tested extracts exert their antibacterial effects on the tested bacteria by attacking the stability of their cytoplasmic membrane. This study provided for the first time data on the mode of action of $K$. senegalensis extracts concerning their antibacterial activity.

\begin{abstract}
Abbreviations
$\mathrm{AlCl}_{3}$ : Aluminium trichloride; Ao: Absorbance of the negative control; AP: Antibiotic Potency; ATCC: American Type Culture Collection; As: Absorbance of test samples; CA-SFM: Antibiotic Committee of the French Society of Microbiology; CFU: Colony format unit; FCR: Folin ciocalteu reagent; GAE: Gallic acid equivalent; HNB: National Herbarium of Benin; MBC: Minimum Bactericidal Concentration; MIC: Minimum inhibitory concentration; $\mathrm{Na}_{2} \mathrm{CO}_{3}$ : Sodium carbonate; OD: Optical densities; RuE: Rutin equivalent; SPSS: Statistical Package for the Social Sciences; YH:Yedomonhan Hounnankpon (ID of the name of the curator of the National Herbarium of Benin); WHO: World Health Organization; WSP-ESI: Water Sanitation Program- Economic and Social Impacts.
\end{abstract}

\section{Acknowledgements}

The authors are very grateful to the World Academy of Sciences (TWAS) and the United Nations Educational, Scientific and Cultural Organization (UNESCO). These two institutions reviewed this research project and provided technical advice on its implementation steps. Finally, they financed this research with funds allocated to the research team under the TWAS Research Grant Award_20-254 RG/BIO/AF/AC_G. They are also grateful to SEEDING LABS who provided useful equipments to the first author's institution, Dr Victorien DOUGNON. They thank Dr Paul LUNGA from Cameroon, who provided great support for performing these analyses.

\section{Authors' contributions}

$H E, D V, A E, A A, S K, S J, B-M L$ wrote the protocol. HE, AE, AA, SK processed the samples. DV, HE, AE did the statistical analyses. HE, DV, AE wrote the draft of the manuscript. DV, SJ, B-ML reviewed the manuscript. All the authors have read and approved the manuscript.

\section{Funding}

This study was funded by The World Academy of Sciences (TWAS) and the United Nations Educational, Scientific and Cultural Organization (UNESCO) under the TWAS Research Grant Award_20-254 RG/BIO/AF/AC_G.

\section{Availability of data and materials}

All data generated or analyzed during this study are included in this published article.

\section{Declarations}

Ethics approval and Consent to participate Not Applicable.
Consent for publication

Not Applicable.

\section{Competing interests}

The authors declare that they have no competing interests.

\section{Author details}

${ }^{1}$ Research Unit in Applied Microbiology and Pharmacology of Natural Substances, Research Laboratory in Applied Biology, Polytechnic School of Abomey-Calavi, University of Abomey-Calavi, Abomey-Calavi, Benin. ${ }^{2}$ Laboratory of Biology and Molecular Typing in Microbiology, Department of Biochemistry and Cell Biology, Faculty of Science and Technology, University of Abomey-Calavi, Abomey-Calavi, Benin.

Received: 16 May 2021 Accepted: 3 June 2021

Published online: 08 June 2021

\section{References}

Abdallah MS, Ahmed I, Yahaya MS (2016) Antibacterial activity and Phytochemical screening of leaf and stem (bark) extract of khaya senegalensis against diarreal/stool isolates. J Microbiol 5(1):17-24

Abdel-Wareth AAA, Hammad S, Ahmed H (2014) Effects of Khaya senegalensis leaves on performance, carcass traits, hemtological and biochemical parameters in rabbits. EXCLI J 13:502-512

Agbankpe J, Dougnon V, Bankolé H, Houngbegnon O, Dah-nouvlessounon D, Baba-Moussa L (2016) In vitro antibacterial effects of Crateva adansonii, Vernonia amygdalina and Sesamum radiatum used for the treatment of infectious diarrhoeas in Benin. J Infect Dis Ther. https://doi.org/10.4172/ 2332-0877.1000281

Ahmed AA, Osman H, Mansour A, Musa HA, Ahmed A, Karrar Z et al (2000) Antimicrobial agent resistance in bacterial isolates from patients with diarrhea and urinary tract infection in Sudan. Am J Trop Med Hyg 63:259-263. https://doi.org/10.4269/aitmh.2000.63.259

Akoègninou A, Van Der Burg WJ, Van Der Maesen LJG (2006) Flore analytique du, Bénin. Backhuys Publishers, Backhuys

Babbar N, Oberoi HS, Sandhu SK, Bhargav VK (2014) Influence of different solvents in extraction of phenolic compounds from vegetable residues and their evaluation as natural sources of antioxidants. J Food Sci Technol 51:2568-2575. https://doi.org/10.1007/s13197-012-0754-4

Borges CV, Minatel IO, Gomez-Gomez HA, Lima GPP (2017) Medicinal plants: influence of environmental factors on the content of secondary metabolites. In: Ghorbanpour M, Varma A (eds) Medicinal plants and environmental challenges. Springer, Cham, pp 259-277. https://doi.org/10.1007/ 978-3-319-68717-9_15

Bourgeois AL, Wierzba TF, Walker RI (2016) Status of vaccine research and development for enterotoxigenic Escherichia coli. Vaccine 34:2880-2886

Bourgou S, Beji RS, Medini F, Ksouri R (2016) Effet du solvant et de la méthode d'extraction sur la teneur en composés phénoliques et les potentialités antioxydantes d'Euphorbia helioscopia. J New Sci 28:1649-1655

Bryce J, Boschi-Pinto C, Shibuya K, Black RE (2005) WHO estimates of the causes of death in children. Lancet 365:1147-1152. https://doi.org/10. 1016/S0140-6736(05)71877-8

CA-SFM (2020) Comité de l'antibiogramme de la Société Française de Microbiologie Recommandations 2020. https://www.sfm-microbiologie.org/ wp-content/uploads/2020/04/CASFM2020_Avril2020_V1.1.pdf. Accessed 12 Feb 2021

Cushnie TPT, Lamb AJ (2005) Antimicrobial activity of flavonoids. Int J Antimicrob Agents 26:343-356

Cushnie TPT, Cushnie B, Lamb AJ (2014) Alkaloids: an overview of their antibacterial, antibiotic-enhancing and antivirulence activities. Int J Antimicrob Agents 44:377-386. https://doi.org/10.1016/j.ijantimicag. 2014.06.001

Dirar Al, Alsaadi DHM, Wada M, Mohamed MA, Watanabe T, Devkota HP (2019) Effects of extraction solvents on total phenolic and flavonoid contents and biological activities of extracts from Sudanese medicinal plants. S Afr J Bot 120:261-267. https://doi.org/10.1016/j.sajb.2018.07.003

Djague F, Lunga PK, Toghueo KRM, Melogmo DYK, Fekam BF (2020) Garcinia kola (Heckel) and Alchornea cordifolia (Schumach. \& Thonn.) Müll. Arg. 
from Cameroon possess potential antisalmonellal and antioxidant properties. PLoS ONE. https://doi.org/10.1371/journal.pone.0237076

Do QD, Angkawijaya AE, Tran-Nguyen PL, Huynh LH, Soetaredjo FE, Ismadji S et al (2014) Effect of extraction solvent on total phenol content, total flavonoid content, and antioxidant activity of Limnophila aromatica. J Food Drug Anal 22:296-302. https://doi.org/10.1016/j.ffda.2013.11.001

Farhadi F, Khameneh B, Iranshahi M, Iranshahy M (2019) Antibacterial activity of flavonoids and their structure-activity relationship: an update review. Phytother Res 33:13-40. https://doi.org/10.1002/ptr.6208

Frirdich E, Whitfield C (2005) Lipopolysaccharide inner core oligosaccharide structure and outer membrane stability in human pathogens belonging to the Enterobacteriaceae. J Endotoxin Res 11:133-144. https://doi.org/ $10.1179 / 096805105 \times 46592$

Ghimire BK, Seong ES, Yu CY, Kim S-H, Chung I-M (2017) Evaluation of phenolic compounds and antimicrobial activities in transgenic Codonopsis lanceolata plants via overexpression of the $\gamma$-tocopherol methyltransferase ( $\gamma$-tmt) gene. S Afr J Bot 109:25-33. https://doi.org/10.1016/j.sajb.2016. 12.022

Houghton PJ, Raman A (1998) Laboratory handbook for the fractionation of Natural extracts, 1st edn. Thomson Publishing, Stamford, pp 154-162

Issa I, Wala K, Dourma M, Atakpama W, Kanda M, Koffi A (2018) Valeur ethnobotanique de l'espèce, Khaya senegalensis (Desr.) A. Juss (meliaceae) auprès des populations riveraines de la chaine de l'Atacora au Togo. Rev Mar Sci Agron Vét 6:64-72

John B, Sulaiman CT, George S, Reddy VRK (2014) Total phenolics and flavonoids in selected medicinal plants from Kerala. Int J Pharm Pharm Sci 6:406-408

Kabir A, Abubakar M, Ugwah-Oguejiofor C, Muhammad A, Usman M, Halilu E (2015) Antidiarrhoel activity of the saponin and flavonoid fractions of Anarcadium occidentale leaves in albino rats. Adv Med Plant Res 3:23-28

Katawa G, Bomboma G, Komi Koukoura K, Ataba E, Ameyapoh A, Amessoudji $O$ et al (2018) In vitro anti-radical and anti-salmonella activities of sarcocephalus latifolius, lannea barteri, uvaria chamae, parkia biglobosa and khaya senegalensis. J Anal Pharmaceut Res. https://doi.org/10.15406/ japlr.2018.07.00213

Klotoé J, Agbodjento E, Dougnon V, Yovo M, Sacramento T, Deguenon ELM et al (2020) Exploration of the chemical potential and antioxidant activity of some plants used in the treatment of male infertility in Southern Benin. J Pharmaceut Res Int 32:1-12. https://doi.org/10.9734/JPRI/2020/ v32i430418

Koudoro YA, Agbangnan DPC, Bothon D, Bogninou SR, Alitonou GA, Avlessi F et al (2018) Métabolites secondaires et activités biologiques des extraits de l'écorce de tronc de Khaya senegalensis, une plante à usage vétérinaire récoltée au Bénin. Int J Innov Appl Stud 23(4):441-450

Kubmarawa D, Khan M, Punah A, Hassan M (2009) Phytochemical screening and antimicrobial efficacy of extracts from Khaya senegalensis against human pathogenic bacteria. Afr J Biotech 7:4563-4566

Lègba B, Dougnon V, Ahoyo A, Agbankpè J, Hounmanou G, Aniambossou A et al (2018) Exploration of the antibacterial and chemical potential of some Beninese pharmacopoiea traditional plants. Microbiol Med 32:149-157. https://doi.org/10.4081/mm.2017.6998

Liu W, Yin D, Li N, Hou X, Wang D, Li D et al (2016) Influence of environmental factors on the active substance production and antioxidant activity in Potentilla fruticosa L. and its quality assessment. Sci Rep 6:28591. https:// doi.org/10.1038/srep28591

Maisetta G, Batoni G, Caboni P, Esin S, Rinaldi AC, Zucca P (2019) Tannin profile, antioxidant properties, and antimicrobial activity of extracts from two Mediterranean species of parasitic plant Cytinus. BMC Complement Altern Med 19:82. https://doi.org/10.1186/s12906-019-2487-7

Miklasińska-Majdanik M, Kępa M, Wojtyczka RD, Idzik D, WąsikTJ (2018) Phenolic compounds diminish antibiotic resistance of Staphylococcus aureus clinical strains. Int J Environ Res Public Health. https://doi.org/10.3390/ ijerph15102321

Mohammedi Z, Atik F (2011) Impact of solvent extraction type on total polyphenols content and biological activity from tamarix aphylla (I.) Karst. Int J Pharm Bio Sci 2:609-615

Nahrgang S, Nolte E, Rechel B (2018) Antimicrobial resistance. European Observatory on Health Systems and Policies.

Olatunji TL, Odebunmi CA, Adetunji AE (2021) Biological activities of limonoids in the Genus Khaya (Meliaceae): a review. Future J Pharmaceut Sci 7(1):74. https://doi.org/10.1186/s43094-021-00197-4
Othman L, Sleiman A, Abdel-Massih RM (2019) Antimicrobial activity of polyphenols and alkaloids in middle eastern plants. Front Microbiol. https:// doi.org/10.3389/fmicb.2019.00911

Pinto NCC, Silva JB, Menegati LM, Guedes MCMR, Marques LB, Silva TPD et al (2017) Cytotoxicity and bacterial membrane destabilization induced by Annona squamosa L. extracts. An Acad Bras Cienc 89:2053-2073. https:// doi.org/10.1590/0001-3765201720150702

Qu M, Lv B, Zhang X, Yan H, Huang Y, Qian H et al (2016) Prevalence and antibiotic resistance of bacterial pathogens isolated from childhood diarrhea in Beijing, China (2010-2014). Gut Pathogens. https://doi.org/10.1186/ s13099-016-0116-2

Saleem S, Muhammad G, Hussain MA, Bukhari SNA (2018) A comprehensive review of phytochemical profile, bioactives for pharmaceuticals, and pharmacological attributes of Azadirachta indica. Phytother Res 32:1241-1272. https://doi.org/10.1002/ptr.6076

Scalbert A (1991) Antimicrobial properties of tannins. Phytochemistry 30:3875-3883. https://doi.org/10.1016/0031-9422(91)83426-L

Singleton VL, Orthofer R, Lamuela-Raventós RM (1999) Analysis of total phenols and other oxidation substrates and antioxidants by means of folinciocalteu reagent. In: Methods in enzymology. Oxidants and antioxidants Part A. Academic Press. https://doi.org/10.1016/S0076-6879(99)99017-1

Trabelsi N, Falleh H, Jallali I, Daly AB, Hajlaoui H, Smaoui A et al (2012) Variation of phenolic composition and biological activities in Limoniastrum monopetalum L. organs. Acta Physiol Plant 34:87-96. https://doi.org/10.1007/ S11738-011-0807-8

Trombetta D, Castelli F, Sarpietro MG, Venuti V, Cristani M, Daniele C et al (2005) Mechanisms of antibacterial action of three monoterpenes. Antimicrob Agents Chemother 49:2474-2478. https://doi.org/10.1128/AAC.49.6. 2474-2478.2005

Tsirinirindravo L, Andrianarisoa B (2010) Activités antibactériennes de l'extrait des feuilles de Dalechampia clematidifolia (Euphorbiaceae). Int J Biol Chem Sci 3(5):1198-1202. https://doi.org/10.4314/ijbcs.v3i5.51098

Ugoh SC, Agarry OO, Garba SA (2014) Studies on the antibacterial activity of Khaya senegalensis [(Desr.) A. Juss)] stem bark extract on Salmonella enterica subsp. enterica serovar Typhi [(ex Kauffmann and Edwards) Le Minor and Popoff]. Asian Pac J Trop Biomed 4:S279. https://doi.org/10. 12980/APJTB.4.2014C636.

Vaara M (1992) Agents that increase the permeability of the outer membrane. Microbiol Rev 56:395-411

Venkatesan T, Choi Y-W, Kim Y-K (2019) Impact of different extraction solvents on phenolic content and antioxidant potential of Pinus densiflora bark extract. Biomed Res Int 2019:1-14. https://doi.org/10.1155/2019/3520675

Vieito C, Fernandes É, Velho M, Pires P (2018) The effect of different solvents on extraction yield, total phenolic content and antioxidant activity of extracts from pine bark (Pinus pinaster subsp. atlantica). Chem Eng Trans 64.

Wang X, Sankarapandian K, Cheng Y, Woo SO, Kwon HW, Perumalsamy H et al (2016) Relationship between total phenolic contents and biological properties of propolis from 20 different regions in South Korea. BMC Complement Altern Med 16:65. https://doi.org/10.1186/s12906-016-1043-y

WHO. Stratégie de I'OMS pour la Médecine Traditionnelle pour 2002-2005. 2002. http://archives.who.int/tbs/trm/s2298f.pdf. Accessed 13 Feb 2021

WHO. The treatment of diarrhoea. WHO 2005. https://www.who.int/maternal child_adolescent/documents/9241593180/en/. Accessed 25 May 2021

WHO. Statistiques Sanitaires Mondiales 2011. World Health Organization; 2011. https:/www.who.int/gho/publications/world_health_statistics/2011/fr/. Accessed 13 Feb 2021

WHO. Statistiques sanitaires mondiales 2014. 2014. https://apps.who.int/iris/ bitstream/handle/10665/112816/WHO_HIS_HSI_14.1_fre.pdf?seque nce $=1$. Accessed 13 Feb 2021

WSP-ESI-Benin. Impacts économiques d'un mauvais assainissement en afrique. 2012. https://www.wsp.org/sites/wsp/files/publications/WSP-ESI-Beninfrench-brochure.pdf. Accessed 13 Feb 2021

Zhishen J, Mengcheng T, Jianming W (1999) The determination of flavonoid contents in mulberry and their scavenging effects on superoxide radicals. Food Chem 64:555-559. https://doi.org/10.1016/S0308-8146(98)00102-2

\section{Publisher's Note}

Springer Nature remains neutral with regard to jurisdictional claims in published maps and institutional affiliations. 